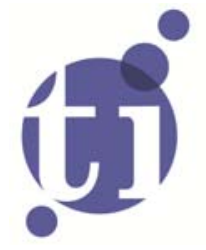

\title{
How do Entrepreneurial Bosses influence their Employees' Future Entrepreneurship Choices?
}

Vera Rochal

Mirjam van Praag ${ }^{1,2}$

' Copenhagen Business School, Denmark;

2 Faculty of Economics and Business, University of Amsterdam and Tinbergen Institute, The Netherlands. 
Tinbergen Institute is the graduate school and research institute in economics of Erasmus University Rotterdam, the University of Amsterdam and VU University Amsterdam.

More TI discussion papers can be downloaded at http://www.tinbergen.nl

Tinbergen Institute has two locations:

Tinbergen Institute Amsterdam

Gustav Mahlerplein 117

1082 MS Amsterdam

The Netherlands

Tel.: +31(0)20525 1600

Tinbergen Institute Rotterdam

Burg. Oudlaan 50

3062 PA Rotterdam

The Netherlands

Tel.: +31(0)10 4088900

Fax: +31(0)10 4089031 


\title{
How do entrepreneurial bosses influence their employees' future
}

\section{entrepreneurship choices?}

\author{
Vera Rocha \\ vr.ino@cbs.dk \\ Copenhagen Business School (INO) and IZA
}

\author{
Mirjam van Praag \\ mvp.ino@cbs.dk \\ Copenhagen Business School (INO), Amsterdam \\ Business School, Tinbergen Institute, CEPR, and \\ IZA
}

\begin{abstract}
We adopt a process-based approach to investigate the influence of entrepreneurial bosses on the two main decisions of employees towards becoming entrepreneurs: exit from the current firm and entry into entrepreneurship. In other words, we study the push and pull mechanisms possibly underlying the influence of entrepreneurial bosses. We do so by employing an identification strategy based on comparisons of same-gender matches of bosses and employees, using rich register data for Denmark. We show that same-gender entrepreneurial bosses have a great impact on employees' future entrepreneurship choices, especially among women. We do not find any evidence that female bosses push female employees out of the workplace, by creating a discriminatory environment that forces them to search for alternative career paths. Instead, our analysis finds consistent support for pull mechanisms, with role modeling being the main explanation for the positive influence of female entrepreneurial bosses on female employees' transition into entrepreneurship. We show that the female boss effect is greater than other social interactions identified in prior research. We conclude that entrepreneurial bosses can be role models and female entrepreneurial bosses may thus act as a lever to reducing gender gaps in entrepreneurship rates.
\end{abstract}

Keywords: Entrepreneurship, role models, gender gaps, female leadership

Acknowledgements: We are grateful for the comments received at ZEW, Copenhagen Business School, Aalborg University, Max Planck Institute, NHH (Bergen), and BI Norwegian Business School on earlier versions of this paper. 


\section{INTRODUCTION}

Entrepreneurship research highlights the importance of social interactions, inside and outside organizations, in shaping individual preferences for entrepreneurship (e.g., Kacperzyk, 2013; Nanda and Sørensen, 2010; Stuart and Ding, 2006). This study contributes to the vibrant literature on the relationship between organizational context and employees' transition to entrepreneurship (Nanda and Sørensen, 2010; Sørensen, 2007; Sørensen and Fassioto, 2011; Sørensen and Sharkey, 2014), by examining a form of social interaction inside organizations that has received little attention in prior research: the interaction between employees and their entrepreneurial bosses (i.e., bosses who are entrepreneurs themselves). We develop a process-based theory to understand how bosses in entrepreneurial ventures might shape their employees' future choices for entrepreneurship. We identify the push and pull effects of bosses on the choice for entrepreneurship by employees based on differences in various career transitions between same-gender bosses and other matches, with a particular focus on female bosses and female employees. We empirically estimate the effect of same-gender entrepreneurial bosses on the two main phases of an employee's decision to become an entrepreneur: the exit from the current firm and the entry into entrepreneurship. In contrast to push factors, we find robust support for the pull factors, which we label "role modeling".

By identifying role modeling based on a comparison of same-gender matches of boss and employee to other matches, our study also contributes to understanding prior theories of gender inequality in entrepreneurship entry. A stylized fact in entrepreneurship research is that entrepreneurship rates are lower among women than men (Thébaud, 2010). Numerous drivers of this gender gap have been analyzed, such as individual disposition, social norms, or shared cultural beliefs associating business ownership with men and stereotypically masculine traits. Recent studies propose that contextual factors may lessen gender differences (Thébaud, 2015), including those able to raise women's self-confidence and self-efficacy, such as sharing an entrepreneurial experience with a female friend (Field et al., 2016) or working closely with female superiors (McGinn and Milkman, 2013). Indeed, emerging discussions on the role of female leadership inside organizations suggest that female bosses (e.g., managers, supervisors, 
CEOs) may influence female employees' values, visions, and goals, and potentially inspire and encourage higher achievements among lower-ranked women in organizations (e.g., Cohen and Broschak, 2013; Foss and Lyngsie, 2016) by acting as role models. To the best of our knowledge, no prior study has investigated to what extent (female or male) bosses can serve as role models in the context of entrepreneurship. A relevant stream of research highlights the importance of (same-gender) role models for an individual's choice for entrepreneurship (Bosma et al., 2012; Greene et al., 2013; Lindquist et al., 2015), but rarely in an organizational context. Female entrepreneurs being role models for their female employees implies a positive spillover effect of female entrepreneurs with personnel on closing the gender gap in entrepreneurship rates.

Our study is based on register data for Denmark and relies on recent methods to analyze this kind of questions, taking into account unobserved characteristics of individuals and their superiors in the organization, and the possible correlation between them (e.g., Lazear et al., 2015; Jackson, 2013). We analyze the labor market transitions of about 89,000 full-time workers hired by 13,931 entrepreneurs of newly founded workplaces, and focus on the differences between same-gender and different-gender matches of entrepreneurial bosses and workers joining entrepreneurial firms, assuming that role models are formed based on homophilic preferences (Bosma et al., 2012; Greene et al., 2013; Lindquist et al., 2015).

Our results indicate that working for an entrepreneurial boss of the same gender increases an individual's likelihood of entering entrepreneurship afterwards. The effect is especially strong for women. We find no evidence that female bosses push female employees out of their companies due to a relatively hostile or unfriendly environment for female employees (e.g., greater gender wage gaps or higher risks of displacement). Instead, our results indicate that female entrepreneurial bosses may be a role model for their female employees, helping attenuating gender-based perspectives and stereotypes related to entrepreneurship. 


\section{ENTREPRENEURIAL BOSSES, GENDER, AND EMPLOYEES' CHOICES FOR ENTREPRENEURSHIP}

Theories of entrepreneurship have resonated that contextual influences drive the entrepreneurial process. Social interactions are one of such contextual influences. They have been proposed to play a role in individuals' decisions to become entrepreneurs, by creating both pecuniary and non-pecuniary benefits (Giannetti and Simonov, 2009). One's social network might offer differential access to information and resources (Gompers et al., 2005; Lerner and Malmendier, 2013), provide learning and motivation (Nanda and Sørensen, 2010; Kacperczyk, 2013), and therefore shape individual career aspirations and attitudes towards entrepreneurship.

The study of social interactions and entrepreneurship has predominantly focused on peer effects, (see Table 1) and mostly outside organizational boundaries. Peers acquainted at education institutions, such as schools (Falck et al., 2012) and universities (Kacperczyk, 2013; Lerner and Malmendier, 2013), have been found to play a role in fostering entrepreneurship intentions and rates of new venture creation. The influence of peers is further documented in groups with different levels of social attachment, such as neighborhoods (Giannetti and Simonov, 2009) and among friends (Field et al., 2016).

Social interactions within organizational boundaries have been relatively less studied as a determinant of individual entrepreneurship choices. This is remarkable given that most entrepreneurs are born in existing organizations (Bhide, 1994; Sørensen and Fassiotto, 2011). Incumbent firms may indeed be arenas for learning about the entrepreneurial process (Gompers et al., 2005; Phillips, 2005; Elfenbein et al., 2010). A few studies have, yet, analyzed the influence of coworkers and confirmed that the nature of an individual's career experiences not only exerts a direct effect on her own knowledge and attitudes, but also "spills over" to colleagues, by influencing the informational and normative environment in which employees make entrepreneurial entry decisions (e.g., Nanda and Sørensen, 2010). In the same vein, Stuart and Ding (2006) have found evidence of peer effects in the context of academic entrepreneurship.

A parallel line of research on social interactions and entrepreneurship has studied the importance of role models. Relative to peers, role models are expected to be hierarchically superior to the focal 
individual and, therefore, more likely to fulfill a mentoring function (Shapiro et al., 1978; Kram and Isabella, 1985; Bosma et al., 2012; Lazear et al., 2015). Entrepreneurial role models have been so far considered outside organizations (cf. Table 1), being often found in the family, and especially among parents (Chlosta et al., 2012; Greene et al., 2013; Hoffman et al., 2015; Lindquist et al., 2015). Evidence for role models' influence has often been identified based on stronger effects of same gender combinations of potential role models and individuals (Gibson, 2004; Barnir et al., 2011; Lindquist et al., 2015), and being more relevant for women than men in the context of entrepreneurship (Greene et al., 2013; Hoffman et al., 2015).

Even though entrepreneurs have been documented to tend viewing former employers and bosses as role models (Bosma et al., 2012), research has remained silent on the possible influence of role models inside organizations (e.g., in the workplace) for one's decision to become an entrepreneur. This study aims at filling this gap, by analyzing the (sorts of) influence of (same-gender) entrepreneurial bosses on employees' future entrepreneurship entry decisions.

\section{*** Table 1 here $* * *$}

\section{Bosses' influence on employees' outcomes}

Why would bosses matter? Bosses are ubiquitous in modern society and nearly all workers have a boss. Nonetheless, standard theories on how (certain) bosses affect employees are at their infancy (Artz et al., 2016). This is remarkable, contrasted with the general interest in peer effects at work (see Cornelissen et al., 2016, and references therein). However, the relationship with one's boss is likely to be at least as important as the one with any other coworker (Lazear et al., 2015), considering the several functions served by bosses (e.g., monitoring, teaching, and motivating their workers).

Recent empirical studies confirm that bosses have a non-negligible role in several outcomes of their employees. Dahl et al. (2012) find that employees' wages can be affected by a male CEO's transition to fatherhood, an event likely to change (male) bosses' managerial style. Lazear et al. (2015) show that bosses vary substantially in their quality (e.g., productivity), thereby considerably influencing the output of their teams of employees. ${ }^{i}$ To put this in perspective, they show that the average effect of 
bosses on employees' productivity is almost twice as large as that of coworkers. Artz et al. (2016) conclude from an analysis of workers' job satisfaction that the perception of the boss' technical competence improves their well-being at the workplace by even more than conventional factors associated with workers' satisfaction, including their remuneration.

The relationship between female bosses and outcomes of female employees has received particular attention in a recent line of research focused on female leadership in organizations. The presence of women in top hierarchies of (mostly large) corporations has been found to influence gender gaps (e.g., in wages, promotion rates), in the sense of narrowing women's relative disadvantages and breaking the so-called "glass ceiling" that often blocks female workers' career progress (Cardoso and Winter-Ebmer, 2010; Matsa and Miller, 2011; Hensvik, 2014).

Theoretical studies indeed point out that female bosses may be agents of change, able to transform social norms, by serving as mentors and role models. First, because bosses face imperfect information about worker productivity, they may rely on certain group characteristics, such as gender, as signals of individual performance and ability. For this reason, female bosses (e.g., CEOs, managers, supervisors) might be better able at inferring other women's unobserved productivity, hence reducing statistical discrimination toward female workers (e.g., Cohen and Huffman, 2007; Cohen and Broschak, 2013; Smith et al., 2013; Hensvik, 2014). Second, theories of taste-based behavior of leaders also predict that a larger representation of women at top hierarchies may reduce a gender bias in the selection of employees, diminish gender wage gaps, and provide more opportunities for women to be promoted (Cardoso and Winter-Ebmer, 2010; Giuliano et al., 2011; Cohen and Broschak, 2013; Hensvik, 2014). Finally, efficiency-based theories postulate that employers may prefer and favor workers of the same type (e.g., race or gender) because of reduced communication costs and consequent efficiency gains (Forbes et al., 2006; Giuliano et al., 2011). All these results are consistent with the "women helping women" hypothesis (Kunze and Miller, 2014).

However, the idea that female-led firms are female friendly has not yet reached a definite consensus. Negative spillovers from female leaders have also been documented. Women in higher ranks 
may instead act as "queen bees" and intentionally hinder the career progress of female workers in lower levels of the job ladder (Bednar and Gicheva, 2014; Maume, 2011; Srivastava and Sherman, 2015). Artz and Taengnoi (2016) for example find that women report lower levels of job satisfaction when their supervisor is also a woman.

Even though research on the role of bosses inside organizations has recently taken off among scholars from different fields, including strategic management, organizational behavior, economics, and sociology, employees' occupational choices still remain under-investigated.

\section{Bosses' influence on employees' entrepreneurship choices: A process-based view}

Existing entrepreneurial process theories are highly fragmented and do not offer yet a solid infrastructure to synthesize the distinct views of transitions to entrepreneurship as a process (Moroz and Hindle, 2012). Moreover, few entrepreneurial process theories explicitly consider social interactions, which contrast with the increasing empirical evidence on the role played by social influences in individual entrepreneurship choices. Greve and Salaff (2003), for instance, theorize and empirically investigate network activities of entrepreneurs through the different phases of establishing a firm, but social interactions in their model take place after individuals decide to establish their own venture. Sarasvathy's (2001) theory of effectuation alternatively suggests that (prospective) entrepreneurs begin with three categories of "means": they know who they are (their own traits, tastes, and abilities), what they know (the knowledge

corridors they are in), and whom they know (the social networks they are a part of). Different sets of contingencies (inside or outside organizations) - including social interactions - ultimately shape individual aspirations, decisions, and the effectuation of the entrepreneurial process.

We build on these prior theories to theoretically frame the role potentially played by entrepreneurial bosses in employees' entrepreneurship choices. We adopt a process-based approach to analyze two main phases in the entrepreneurial entry process - the exit from paid employment and the entry into entrepreneurship - by considering the influence of the boss on each of these two stages. ${ }^{\text {ii }}$ 
Bosses can both push and pull their employees into entrepreneurship. On the one hand, (certain) bosses can create a hostile setting in the workplace, for instance by blocking employees' career progress, discriminating against certain groups of workers, and increasing wage inequality and job dissatisfaction (Bagues and Esteve-Volart, 2010; Lyness and Heilman, 2006; Artz and Taengnoi, 2016). If bosses, first and foremost play a role in employees' exit decision, their eventual transition into entrepreneurship can be perceived as a pushed- or necessity-driven decision (e.g., Hughes, 2003).

On the other hand, (certain) bosses can affect an employee's transition into entrepreneurship by exerting a positive influence, by working as a mentor, a role model (Kram and Isabella, 1985; Gibson, 2004), and by providing motivation and entrepreneurial learning. Bosses can be a source of inspiration and help demystifying the entrepreneurial process, and, thus, promote their employees' decision to become entrepreneurs themselves, without necessarily pushing them out of the workplace. In this case, an employee's choice for entrepreneurship would be mostly driven by pull factors.

Bosses can therefore impact employees' entrepreneurship choices in different ways. Furthermore, specific (entrepreneurial) bosses might be more influential for specific employees. Scholars consistently show that social interactions are partially driven by homophily, meaning that people associate most often and most strongly with others who are similar to themselves, also in organizational settings (McPherson et al., 2001; Reagans, 2005; 2011). Resemblance between individuals is demonstrated to increase communication (Kleinbaum et al., 2011; Reagans, 2011) and consideration for the knowledge transmitted by others (Golub and Jackson, 2012; Kane, 2010). Demographic homophily in particular, namely gender similarity, is found to affect an individual's social interactions with both peers at work (e.g., Kleinbaum et al., 2011) and workgroup superiors (e.g., McGinn and Milkman, 2013), with non-negligible implications for individuals' career mobility. Therefore, we specifically investigate the influence of same-gender bosses on employees' entrepreneurship choices. 


\section{Employee-boss gender match and (female versus male) employees' entrepreneurship choices}

We theorize that entrepreneurial bosses can have a greater impact on employees' future entrepreneurship choices when they are similar in attributes, such as gender. Peer effects in the context of entrepreneurship are likely to be stronger between same-gender dyads (e.g., Kacperczyk, 2013; Field et al., 2016), and prior work on the intergenerational transmission of entrepreneurship further finds that entrepreneurial mothers and fathers are stronger role models for daughters and sons, respectively (Greene et al., 2013; Hoffman et al., 2015; Lindquist et al., 2015). In a variety of contexts, role models are often found within same-gender lines (McPherson et al., 2001; Gibson, 2004; Barnir et al., 2011).

Role identification and social learning theories broadly define role models as cognitive constructions based on individuals' perceptions to be similar to some extent to persons in social roles, and their desire to increase this perceived similarity through the emulation of those attributes and the achievement of similar goals (Shapiro et al., 1978; Gibson, 2004; Barnir et al., 2011; Bosma et al., 2012; Obschonka et al., 2012; Greene et al., 2013). Role models are therefore viewed as examples to be followed and believed to serve several interrelated functions. Besides providing learning, motivation and inspiration, support and guidance, they may also help individuals to increase their self-efficacy (Shapiro et al., 1978; Gibson, 2004; Barnir et al., 2011). They are expected to transfer or impute preferences (and even abilities) for certain occupations and/or lifestyles, through observation and social interaction (Hoffman et al., 2015). Therefore, bosses who are also entrepreneurs may have a role modeling function, by possibly providing entrepreneurial learning and knowledge spillovers, legitimizing entrepreneurial aspirations and actions, reducing uncertainty about the entrepreneurial process, and creating several nonpecuniary benefits among their employees - especially those similar to them in certain attributes such as gender (Barnir et al., 2011; Bosma et al., 2012; McGinn and Milkman, 2013).

Same-gender entrepreneurial bosses may nevertheless have different roles and fulfill different needs among male and female employees. Prior research on female leadership shows women's upward mobility (i.e., promotions) to be more affected by same-sex superiors (McGinn and Milkman, 2013). Part

of the explanation resides in female seniors being (stronger) role models to lower-ranked women in 
organizations, by providing motivation and information to junior women that they could also succeed, while junior men often take the possibility of success for granted. Similar results and explanations have been provided by other studies, either looking at promotion rates or gender wage gaps inside organizations (e.g., Cohen and Broschak, 2013; Cohen and Huffman, 2007). The fact that women in top hierarchies are typically an underrepresented minority may strengthen the ties with other women in the firm, and therefore explain why men and women may be differently affected by same-gender bosses (McGinn and Milkman, 2013; see also Reagans (2005) for a context where men represent the minority).

Likewise, also when considering career choices related to entrepreneurship, female entrepreneurial bosses may exert a greater influence on female employees' entrepreneurial preferences than male entrepreneurial bosses might do among male employees. First, women score lower, on average, than men in many behavioral traits that are related to entrepreneurship, such as risk aversion (Charness and Gneezy, 2012), competitive attitudes (Gneezy and Rustichini, 2004), and entrepreneurial self-efficacy (i.e., one's belief regarding the ability to carry out tasks related to starting and running a new venture e.g., Barnir et al., 2011). The exposure to entrepreneurial role models may accordingly fulfill a much greater motivational role for women and affect their behavior more strongly (Wilson et al., 2007; Thébaud, 2010; Barnir et al., 2011; Koellinger et al., 2013; OECD, 2014).

In addition, prior studies find that those who are less exposed to entrepreneurship tend to be more strongly affected by the interaction with experienced entrepreneurs (Nanda and Sørensen, 2010; Obschonka et al., 2012), and women are indeed less likely to have an entrepreneurial experience (Koellinger et al., 2013) or to report knowing an entrepreneur, compared to men (Kelley et al., 2012).

Finally, the historical lack of female entrepreneurs, and consequently the scarcity of female role models in entrepreneurship, has probably also induced fewer women to become entrepreneurs over time (Hoffman et al., 2015). Women who break traditional gender roles in the labor market are believed to encourage other women to invest in similar career paths (Cohen and Broschak, 2013; Smith et al., 2013). The existence of female role models may, thus, attenuate gender-based perspectives, stereotypes, and 
women's general disadvantages (e.g., in the search for credit), by providing other women with the stimulus and access to resources that may not exist otherwise (Thébaud, 2010; Field et al., 2016).

While female entrepreneurial bosses may be role models and, thus, pull their female employees into an entrepreneurial career, other mechanisms might explain the possible influence of same-gender bosses on employees' preferences for entrepreneurship, especially among women. Female employees may be induced to leave organizations to a higher extent than men when the entrepreneurial boss is also female, due to limited career advancement opportunities and discrimination (Buttner and Moore, 1997; Hughes, 2003). If female entrepreneurial bosses act as "queen bees" in the organization and favor male over female workers (Lyness and Heilman, 2006; Maume, 2001; Bagues and Esteve-Volart, 2010; Srivastava and Sherman, 2015), female employees might decide to leave and eventually enter entrepreneurship, to escape from situations of wage inequality, increased risk of displacement, or dissatisfaction with the current boss. In this case, the impact of the (same-gender) boss on the employee's choice for entrepreneurship takes place primarily in the employee's exit decision. This implies that (certain) employees might instead be pushed into entrepreneurship by (certain) bosses.

\section{DATA AND METHODS}

\section{Data Sources and Sample}

Our analysis is based on register data maintained by Statistics Denmark - the Integrated Database for Labor Market Research, referred to by its Danish acronym IDA. These data are attractive for this study for several reasons. First, it is comprehensive, covering everyone legally living in Denmark from 1980 until 2012, and providing detailed yearly socio-economic data at the individual level. Second, it covers a wide range of labor market phenomena, allowing to construct workers' career histories (including transitions between occupations, firms, and different bosses), which will be crucial to characterize individuals' past experience. Finally, IDA is a longitudinal matched employer-employee dataset, which means that employees can be linked to their employers over time. This unique feature of the data allows us to identify the interaction between employees and their (different) bosses at the workplace level. 
We construct our sample with three important factors in mind. First, we focus on brand new and independent firms, i.e., newly founded workplaces without any connection to an existing company. This implies that new workplaces created through separations from other firms or mergers of existing plants are excluded from our sample. This approach reduces the sources of heterogeneity related to the origin of the new venture and allows us to better identify entrepreneurial bosses, as we define below. Second, given that entrepreneurship is a relatively rare event on an annual basis, we study employees' likelihood of becoming an entrepreneur during multiple years. This generates better power in our estimations, besides guaranteeing that our results are not driven by the specifics of one given year. Finally, we also want to use explanatory variables characterizing individual career histories, as well as to study outcomes, in particular the hazard of transitions into entrepreneurship after employment spells in entrepreneurial firms. Therefore we need to cover three sub-periods: employees' prior career histories, their exposure to entrepreneurial bosses in newly founded ventures, and their future career choices.

Besides these sampling criteria, prerequisites to our analysis include clear and proper definitions of bosses and workers' transitions into entrepreneurship. Based on the classification of individuals' primary occupation, the boss is defined as the employer at the workplace. Since we focus on newly founded workplaces, which are mostly micro-sized, the founding business owner corresponds to the boss, allowing us to focus on entrepreneurial bosses, i.e., bosses who are entrepreneurs themselves. ${ }^{\text {iii }}$ We exclude the cases in which the boss is a family member of the employee (e.g., father, mother, spouse) to avoid confounding explanations of the role of the boss. Moreover, we exclude newly founded workplaces started up by teams of entrepreneurs, in which case the (main) boss is less clearly identified. ${ }^{\text {iv }}$

Similarly, we leave out from our analysis "non-entrepreneurial" bosses - i.e., bosses in established (non-entrepreneurial) firms, even though this category of bosses might have served as a possible control group to compare entrepreneurial bosses to. They are excluded from the sample because the (main) boss with whom each employee interacts in a larger organization is difficult to identify. Furthermore, individuals with distinct entrepreneurial preferences tend to sort into small and young firms (Dinlersoz et al., 2016), being therefore not directly comparable to employees of established companies. ${ }^{\mathrm{v}}$ 
We therefore use the employee-boss gender match in newly founded ventures to identify the (push versus pull) mechanisms through which the entrepreneurial boss might affect their employees' entrepreneurship choices.

The identification of workers' transitions into entrepreneurship is also based on the classification of individuals' primary occupations every year. We use both a broad and a strict entrepreneurship definition. The broad definition includes registrations as self-employed (with or without employees), employers, and founders of new businesses (according to the Statistics Denmark Entrepreneurship Database register). The stricter definition considers as entrepreneurs only those who employ at least one wage earner at the year of entry into entrepreneurship, like the "bosses" in our sample. These entrepreneurs are more likely to have higher ambition and growth intentions than self-employed individuals (Henrekson and Sanadaji, 2014).

Our final sample covers all new workplaces founded between 2003 and 2007 where we can identify the entrepreneurial boss and which employ at least one employee at the end of the entry year. Data prior to 2003 are used to describe workers' and bosses' labor market histories. We focus our analysis on full-time workers, a group that is expectedly homogeneous in their engagement level in the workplace and that is more likely to closely interact with - and, thus, be affected by - their boss. We follow all these workers since they join the firm until they leave (and eventually enter entrepreneurship) or until the last year of available information (right-censoring). This sample structure allows us to use discrete-time event history models to study workers' transition into entrepreneurship.

Our final sample is composed of 13,931 newly founded workplaces with a known and unique employer (the boss). Twenty nice percent of the entrepreneurs $(4,036)$ are female. We identify a total of 89,189 full-time workers, with no other primary occupation, hired at these workplaces over time. A total of 1,966 workers become entrepreneurs (broader definition) after leaving the workplace, out of which $32 \%$ also employ labor in the year of transition (stricter definition). The share of women among those becoming entrepreneurs varies between $29 \%$ and $31 \%$, according to the entrepreneurship definition used. 
Descriptive statistics for the 89,189 full-time workers hired at those newly founded workplaces are shown in Table 2, separately for future entrepreneurs and those never switching to entrepreneurship during the period observed. We provide separate statistics for males and females in the Appendix (Table A.I). Table 2 further compares future entrepreneurs with those who leave the firm but not to entrepreneurship (e.g., movers to other firms).

On average, employees who become entrepreneurs are older and have higher education levels than other peers in paid employment. These differences are especially evident among women (see Table A.I). Future entrepreneurs are more often married, worked in a greater number of different workplaces before, and had longer spells in unemployment in the past on average. All these differences are even more evident when we compare future entrepreneurs with other movers who chose different paths than entrepreneurship. Apparently the difference between those who move out of an entrepreneurial firm and those who stay is not a "mover-stayer difference" (Elfenbein et al., 2010).

Workplaces spawning new entrepreneurs among employees tend to be smaller, in line with prior studies, although in this case we include only newly started entrepreneurial firms in our sample, both small and large (e.g., Dobrev and Barnett, 2005; Parker, 2009). While a strong presence of women in the workforce and female bosses seem to be negatively associated with the overall propensity to become an entrepreneur, the opposite pattern is observed when we look at women - female workers entering entrepreneurship had more often a female boss and a larger share of female peers in the workplace (see Table A.I). These patterns may be partially explained by the different industry distribution of female and male bosses (see Table A.II in the Appendix). While the businesses run by female bosses are more often found in wholesale and retail trade, accommodation and food services, business services, and educational and healthcare services, a considerable share of male bosses are found in construction, the primary sector, and in transport and storage services. We acknowledge these differences in the industry distribution and (consequent) workforce composition of workplaces as potential determinants of workers' transition into entrepreneurship, and therefore we control for all these factors and possibly correlated unobserved factors determining them in our estimations. 
$* * *$ Table 2 here $* * *$

\section{Methods}

An essential aspect of our empirical analysis involves accounting for a number of selectivity issues driven by unobserved attributes of both bosses and workers, which may bias our results if neglected. Bosses and workers are, of course, heterogeneous with respect to a number of aspects we cannot observe, such as their innate ability or quality, entrepreneurial talent or preferences for certain work environments. These unobserved traits (which we refer to as unobserved heterogeneity) are likely to (partly) drive their mobility decisions. Bosses may select (or leave) employees, and employees may select (or leave) bosses. This switching may be non-random but driven by both boss and employees' characteristics that are partly unobserved to us, such as their quality (e.g., Lazear et al., 2015). These issues imply that workers and bosses are not randomly assigned to each other (see also Giuliano et al., 2011; Kunze and Miller, 2014). Instead, there is a potential assortative matching (partly) based on their unobserved attributes, which means that employees' and boss' unobserved quality are correlated. This also means that the worker-boss match is likely to be endogenous.

We address these issues using recently developed multi-level mixed-effects models (Abowd et al., 2008; Rabe-Hesketh and Skrondal, 2012; Woodcook, 2015), which combine features of both fixed and random effect estimators. Similar to Lazear et al.'s (2015) method to study the role played by bossed in worker's productivity, our approach addresses the possible unobserved sorting effects mentioned above by allowing heterogeneous workers to be grouped with heterogeneous bosses. The great advantage of this method is that it allows for the effect of a boss to vary from worker to worker, depending on the quality of their match, besides taking into account workers' and bosses' unobserved traits. Thus, the most likely source of non-random sorting - i.e., through assignment based on worker-boss (unobserved) match quality - is also captured in this model.

Given the time-to-event structure of our dataset, we estimate multi-level mixed effects models for discrete time duration data to study the entrepreneurial entry decision of full-time workers employed in newly founded workplaces. The probability of each worker $i$, with boss $b$, leaving the workplace to enter 
entrepreneurship in the year $t+1$, will be modeled as a function of worker's gender, worker-boss gender similarity, and the interaction between the two, always controlling for several worker and boss characteristics (see Table 2), year, region, and industry fixed effects. The baseline three-level mixed model for the worker's probability of transiting into entrepreneurship in $t+1$ can be written as follows:

$\operatorname{Pr}\left(E_{i b t+1}=1\right)=H\left(\beta_{1} F_{i}+\beta_{2} S G_{b}+\beta_{3} F_{i} \cdot S G_{b}+\boldsymbol{X}_{i t} \boldsymbol{\alpha}+\boldsymbol{Z}_{b t} \boldsymbol{\delta}+\tau_{t}+\gamma_{y}+\mu_{j}+\lambda_{r}+\zeta_{i b}^{(2)}+\zeta_{b}^{(3)}+\varepsilon_{i b}\right)$

where $F_{i}$ and $S G_{b}$ indicate, respectively, whether the employee is a woman and whether the boss is of the same gender; $\boldsymbol{X}_{i t}$ and $\boldsymbol{Z}_{b t}$ are a set of employee and boss characteristics; $\tau_{t}$ denotes duration (employee's tenure) dummies; $\gamma_{y}, \mu_{j}$, and $\lambda_{r}$ are year, industry (2-digit), and region fixed effects; $\zeta_{i b}^{(2)}$ and $\zeta_{b}^{(3)}$ are the employee-level and boss-level random effects, with zero mean and variances $\psi^{(2)}$ and $\psi^{(3)}$, respectively; $\varepsilon_{i b}$ is the level 1-error term; and $H(\cdot)$ is the inverse of the complementarity log-logistic function. Time subscripts are omitted from the right-hand side of the equation for simplicity of the notation.

Robustness checks extend this baseline specification by using alternative definitions for the exposure to same-gender bosses in the current firm and by adding further controls related to previous interactions with same-gender bosses in other firms. To further test the consistency of our results and the validity of the econometric method to capture some likely biases caused by endogenous worker-boss sorting, we also re-estimate this baseline specification in several sub-samples where the selectivity issues previously described are less likely to be an issue. We refer to these results in the next section.

\section{RESULTS}

\section{Same-gender entrepreneurial bosses and employees' future transition into entrepreneurship}

We start by estimating equation (1) for all the full-time workers hired at new firms founded between 2003 and 2007 by a known entrepreneurial boss. We perform separate estimations for female and male workers to infer about the (possibly different) effects exerted by same-gender bosses on each of these groups.

Table 3 summarizes the key results obtained for both definitions of entrepreneurship. The coefficients obtained for control variables are presented in the Appendix (Table A.III). 
*** Table 3 here ***

The results indicate that female employees are more likely to leave paid employment and become entrepreneurs when the entrepreneurial boss is also a woman. The estimated coefficient is even larger when using a stricter definition of entrepreneurship. The predicted entrepreneurship probability of a woman with average characteristics (e.g., age, labor experience) is $49 \%$ higher when the boss is also a woman, compared to when the boss is a man $(78 \%$ higher when using the stricter entrepreneurship definition). Although the coefficient of Same-gender Boss is also positive for male employees, it is either insignificant (broader definition) or marginally significant (stricter definition).

These first results therefore suggest that working for an entrepreneurial boss of the same gender is positively associated with an employee's propensity to become an entrepreneur as well, especially among women. The results are robust to the following alternative specifications. The results remain qualitatively the same when using various alternative measures for the exposure to a same-gender boss in the organization, such as the number of different previous bosses of the same gender or the share of the employee's tenure/total experience with a same-gender boss (not reported, but available upon request). The results reported in Table 3 remain also qualitatively unchanged when repeating these estimations in sub-samples where non-random assignment of workers to bosses (and vice-versa) is less likely to be a problem, which attests the validity of our method in tackling these issues. First, we excluded those few cases where the founder was replaced by another boss during the period observed, in order to eliminate the concerns about non-random mobility of bosses. We also repeated the analysis for employees hired after having been displaced from a previous firm due to closure. These individuals are more likely to have faced an exogenous shock that forced them to move to another firm (and boss). They are therefore expected to select the new boss more randomly. Alternatively, we restricted the estimation to the very first hires of these newly founded businesses. Given that they have less information about the quality of the firm and the boss as an entrepreneur, they are also believed to be less driven by factors that we cannot observe. The results also hold when we restrict the estimation to workers hired at later stages of the firm lifecycle, when founders may be more willing to take the risk of hiring employees outside their network, 
and about whom they might have less information than those hired in early stages. Finally, the results remain qualitatively similar when restricting the sample to workplaces that remain active until the end of the observed period. This indicates that the positive effect of female bosses on female employees' propensity to enter entrepreneurship afterwards is not driven by a higher failure risk of female entrepreneurs (which would increase unemployment risks and possibly push them into entrepreneurship). Although omitted to save space, all these robustness checks are available upon request.

The results obtained for the set of control variables (Table A.III) are in line with prior evidence found in the literature. The likelihood of entering entrepreneurship increases with a worker's age (at a decreasing rate), education, and is higher for married individuals (e.g., Koellinger et al., 2013). Workers with a more diversified labor experience (in terms of number of different workplaces where they were employed before) are also more likely to become entrepreneurs, consistent with Lazear's Jack-of-AllTrades hypothesis (Lazear, 2005)). Longer spells in unemployment prior to the current job, on the other hand, seem to decrease the likelihood of leaving wage employment to become an entrepreneur, consistent with higher opportunity cost of leaving the current job for entrepreneurship for those workers who experienced longer unemployment periods in the past.

Similar to prior studies (Sørensen, 2007; Parker, 2009), workers' entrepreneurial propensity is negatively related to the size of the workplace. Even though workers may self-select into workplaces of different sizes with the intention of learning from small businesses' owners, the fact that our methods control for workers' unobserved traits (which may include permanent preferences for entrepreneurship) mitigates the potential bias in our main results of interest caused by this selectivity issue.

\section{The effect of same-gender bosses, peers, parents, and spouses}

Our results so far demonstrate that the exposure to a same-gender entrepreneurial boss inside organizations increases the employees' propensity to enter entrepreneurship afterwards, and that this effect is stronger for female than for male employees, as expected. We wish to compare the size of the positive effect of same-gender entrepreneurial bosses on the likelihood of employees' becoming 
entrepreneurs to other social interactions studied previously (cf. Table 1). Therefore, before delving deeper into the mechanisms underlying the same-gender boss effect, we first compare the influence of same-gender bosses with that of peers, parents, and spouses with entrepreneurship experience. To this end we extend the previous specifications for men and women by including a) the share of (female versus male) coworkers in the organization with entrepreneurship experience, b) a variable indicating whether the spouse is an entrepreneur, and c) two variables indicating whether any of the parents (mother versus father) has an entrepreneurial occupation. In order to compare the relative size of each effect we use $\mathrm{z}$ standardized coefficients. The results are summarized in Table $4 .{ }^{\mathrm{vi}}$

$$
* * * \text { Table } 4 \text { here } * * *
$$

We confirm that peers influence individuals' future entrepreneurship choices (Nanda and Sørensen, 2010), and particularly same-gender peers (Kacperczyk, 2013). Entrepreneurial parents, and especially entrepreneurial fathers, also play an important role for individuals' entrepreneurship choices (e.g., Hoffman et al., 2015; Lindquist et al., 2015). Entrepreneurial fathers are actually found to be the only significant social influence on male employees' transitions into entrepreneurship. Female employees' preferences for entrepreneurship seem to be shaped by their father's and mother's careers as a business owner. The coefficient for Mother Entrepreneur is larger and positive in the female sample, which is aligned with the evidence that mothers' occupation is more likely to influence the career choices of their daughters than those of their sons (e.g., Greene et al., 2013; Lindquist et al., 2015), though the lack of entrepreneurial mothers in the sample seems to have affected the significance of the estimate. ${ }^{\text {vii }}$

The results show that the same-gender boss effect previously found in the female sample remains statistically significant even after controlling for all these other social interactions with other entrepreneurs, both inside the organization and among close relatives. Same-gender bosses are found to play the largest role for women's entrepreneurship decisions, by exerting an impact that is more than two times larger than that of an entrepreneurial father, and almost three times larger than that of female coworkers with prior experience in entrepreneurship. The effect of same-gender bosses is further found to be larger than more traditional determinants of entrepreneurship transition, such as education. According 
to the results obtained for control variables (not reported), the female boss effect is about twice as large as the effect of a higher education degree.

The relatively greater impact of female bosses is even more remarkable when we focus on transitions into entrepreneurship according to the stricter definition (i.e., the decision to startup and hire personnel already in the first year - Table 4.2). We now turn to possible mechanisms underlying the large effect of female bosses on their female employees' entrepreneurship choices.

\section{UNDERLYING MECHANISMS}

\section{Push Factors}

To what extent are female employees pushed into alternative career paths such as entrepreneurship because of a less friendly or even hostile environment created by their female entrepreneurial bosses in the workplace? Given that we are analyzing newly founded small ventures where the entrepreneurial boss is also the employer, we believe that the so-called "queen bee" syndrome (e.g., Hughes, 2003; Maume, 2001; Srivastava and Sherman, 2015) may be less relevant than it could be in larger organizations, where female leaders may not have a direct role in recruitment. Even so we investigate the (direct and indirect) influence of female bosses in employees' exit decision, by testing whether female employees with female entrepreneurial bosses end up in more disadvantaged positions (relative to their male counterparts) than female employees with a male boss. We look at the employees' probability of moving from the current workplace to a different organization, their risk of becoming unemployed, and their hourly wage in the current firm. Table 5 summarizes the key results. We employ multi-level mixed models for all the three outcomes, to overcome biased effect measures due to selectivity issues.

$$
* * * \text { Table } 5 \text { here } * * *
$$

The results show that female employees earn significantly lower wages and have a higher probability of moving to another job, after controlling for several individual, workplace, and boss characteristics (including the unobserved quality of the employee-boss match). The exposure to a female 
entrepreneurial boss is found to increase the probability of leaving the firm, either to another firm or to unemployment. Female entrepreneurial bosses also pay lower wages than their male counterparts. However, the results indicate that female employees are relatively more protected when they work for a female entrepreneur, rather than a male entrepreneur: they have a lower propensity to leave to another job, they are less exposed to the risk of becoming unemployed afterwards, and the negative wage differential relative to male employees is narrower when the boss is female.

Overall, the results do not provide any evidence of female bosses favoring men over women in the workplace. Instead, female bosses may actually help narrowing existing gender wage gaps (see also Cohen and Huffman, 2007; Cardoso and Winter-Ebmer, 2010). We conclude that female bosses are not pushing female employees into alternative career paths such as entrepreneurship.

\section{Pull Factors}

We have demonstrated that same-gender bosses increase the likelihood of future entrepreneurship choices of female employees, while we have ruled out push factors as an explanation. Based on our theory, a remaining candidate mechanism explaining the result may be that female entrepreneurial bosses act as role models for their female employees. We now delve deeper into the pull factors that might explain the positive influence of female bosses.

First, we investigate how the effect of female entrepreneurial bosses varies with two characteristics of the organization - its size and the relative presence of female peers. Our previous results showed that the employees' propensity to enter entrepreneurship in the near future is inversely related to the size of the workplace. By extending those baseline estimations in the sample of female employees, we verify that this result is even stronger when the boss is a woman (first column of Table 6). The smaller the workplace, the closer the interaction with the entrepreneurial boss, which may better promote the transmission of entrepreneurial self-efficacy, knowledge, and inspiration from the boss to the employee. In addition, the female boss effect is greater when the share of female coworkers in the organization is smaller (second column of Table 6). On the one hand, female employees may be more inspired by female 
bosses leading male-dominated workforces, whom they may view as stronger female leaders. On the other hand, the transmission of entrepreneurial knowledge and intentions may be stronger when the employee does not have to share the boss' attention with same-gender peers. Similar results and explanations are provided by Lindquist et al. (2015), who find the number of same-sex siblings to moderate the effects for same-sex parent-child transmission of entrepreneurship intentions.

We additionally test the difference in the female boss effect between male- and female-dominated industries (last two columns of Table 6). Male- (female-) dominated industries are defined as (2-digit) industries where, in each year, the average share of female employees in firms' total workforce is smaller (larger) or equal to $25 \%(75 \%)$. The results show that the female employees' future choices for entrepreneurship are more strongly influenced by their female boss in male-dominated sectors. Once again, this might indicate that female entrepreneurs running businesses in sectors traditionally dominated by men provide more inspiration and increase other women's entrepreneurial self-efficacy to a larger extent.

We next investigate how the effect of female entrepreneurial bosses varies with the performance of the firm (Table 7). To this end, we repeat the estimations for female employees in high- and lowperformance firms - i.e., workplaces with an annual performance above and below the yearly median performance in the sample of newly founded workplaces. We use two measures for performance: sales and labor productivity (the ratio between sales level and total employment, observed by the end of each year). The results show that the female boss effect is greater and more significant in high-performance firms. Together with the stronger effects previously found in male-dominated industries, these results also indicate that female employees deciding to become entrepreneurs after having worked for a female entrepreneurial boss are mostly driven by other women breaking traditional stereotypes, i.e. successful female entrepreneurs in sectors traditionally dominated by men. These examples may indeed be more effective in improving other women's entrepreneurial self-efficacy, thus providing stronger role models.

Finally, we investigate how the female boss effect changes with worker-boss homophily in other characteristics (Table 8). As discussed before, role identification and social network theories suggest that 
individuals tend to associate disproportionately with those having similar traits (which usually include, besides gender, age, race, profession, and education levels), and that role modeling effects, mentoring, and knowledge transmission tend to be more effective as more types of similarities exist between individuals (Gibson, 2004; Golub and Jackson, 2012; Kane, 2010; McPherson et al., 2011). We look at worker-boss homophily in age and educational background (both the level and the field of education), two dimensions of homophily that are often referred to as being important in the context of entrepreneurial teams and networks (Ruef et al., 2003; Forbes et al., 2006). ${ }^{\text {viii }}$ We additionally test whether the female boss influence varies with the similarity regarding their birth place and their family composition (namely the fact of having children), two other dimensions that might increase identification. We find that the worker-boss similarity in all these dimensions reinforces the positive effect that female bosses have on other women's entrepreneurship entry rates. The transmission of entrepreneurial behavior seems to be more likely when employees and bosses are similar in several characteristics.

*** Tables 6 to 8 here $* * *$

Overall, the results that smaller and successful firms in more male-dominated industries, as well as more homophilic female bosses enforce the effect of these bosses on the likelihood of female employees entering entrepreneurship paint a clear picture: Bosses in entrepreneurial ventures can act as role models for the future entrepreneurship activities of employees.

\section{DISCUSSION}

Entrepreneurial role models are viewed as a possible source of relevant human and social capital. A better understanding of this potential driver of entrepreneurship may lead to the development and use of additional (policy) instruments to enhance entrepreneurial activity and outcomes, especially among individuals who may be less inclined to engage in entrepreneurial activities, but not necessarily less able to perform well as entrepreneurs, such as women (OECD, 2014).

This study shows that same-gender entrepreneurial bosses play a large role in their employees' probability of entering entrepreneurship afterwards, especially among women. We do not find any 
evidence that female bosses push female employees out of the workplace, by creating a discriminatory environment that forces them to search for alternative career paths. Instead, our analysis finds consistent support for pull factors, with role modeling being the main underlying explanation for the positive influence exerted by female entrepreneurial bosses on female employees' transition into entrepreneurship. The female boss effect is found to be stronger when the employee-boss interaction is closer (smaller organizations with fewer female peers), when the firm operates in a male-dominated sector and has relatively high performance, and when the female boss and the female employee are identical in further characteristics (age, education background, birth place, and motherhood).

\section{Theoretical and Empirical Contributions}

To the best of our knowledge, this is the first study of the impact of (entrepreneurial) bosses on future entrepreneurship choices of their current employees, and of the mechanisms underlying this effect. Using rich register data for Denmark, and empirical methods that take into account the unobserved quality of the match between each employee and her boss, we investigate the role of a particular social interaction inside organizations in (differentially) stimulating male and female employees to become entrepreneurs: the exposure to same-gender entrepreneurial bosses.

Our findings represent a significant contribution to existing theories and to recent empirical evidence regarding social transmission of behaviors and attitudes across individuals in the context of entrepreneurship. In the same vein as Lindquist et al. (2015), we infer from the strong same gender link that the transmission of entrepreneurship from boss to employee may be explained by role modeling. Even stronger, we show that this transmission is economically more important for the transmission of entrepreneurship in this context than any other social interaction previously studied. We also contribute to previous theories of gender inequality in entrepreneurship entry, by theorizing and empirically validating that the organizational context, namely the interaction with bosses who are entrepreneurs themselves, may mitigate the gender gaps in entrepreneurial self-efficacy, risk taking preferences, and competitive attitudes that partly explain the lower entrepreneurship rates among women. 
More broadly, our study may also be viewed as a contribution to the growing debate on gender diversity in company boards. In this debate, a common justification for the desirability of gender diversity in top management teams is the spillover effect of female board members to future female board members (e.g., Dezsö and Ross, 2012; Foss and Lyngsie, 2016) and women in lower ranks (e.g., Bagues and Esteve-Volart, 2010; Cardoso and Winter-Ebmer, 2010). While most of these studies have been looking at large companies, evidence on newly founded, smaller, companies where workers tend to be differently exposed to their boss was still rare. By studying new workplaces where bosses are also entrepreneurs, hierarchies are flatter, and employee-boss interactions are closer, we are able to obtain clearer effects of the exposure to same-gender (entrepreneurial) bosses on employees' (entrepreneurship) outcomes.

\section{Implications for Practice and Policy}

Our findings indicate that entrepreneurial role models may provide a different functionality for men and women. Role models may be especially relevant for women, offering them relatively more training, advice, motivation, and instructional support related to entrepreneurship activities, as women lack them to a higher extent compared to men. Furthermore, given the changing roles and stereotypes of women, it is also possible that women are more open to input from role models than men.

This paper also adds new insights to the increasing public discussion on the extent to which role models can be a policy instrument. The historical lack of female entrepreneurs, and consequently the lack of female role models, may thus be part of the reason for the fewer women among entrepreneurs today. Changing this pattern requires a concerted political effort building on attentive ways of providing female entrepreneurial role models. Role models may change perceptions of self-efficacy and set meaningful examples, so publicizing (female) entrepreneurial successes that are credible role models may increase women's perceptions that starting a business is indeed feasible, and make vicarious learning possible.

\section{Limitations and Future Research}

Studying newly founded small-sized workplaces provides a pertinent setting to investigate the effect of same-gender entrepreneurial bosses on employees' future entrepreneurship choices, by making sure that employees are more directly exposed to their boss than in large, incumbent, corporations. This empirical 
setting also allows us identifying entrepreneurial bosses in a clearer way than using larger and more mature ventures. However, we acknowledge that (female) employees joining these firms may be different from other (female) employees joining larger established companies. This issue is, however, mitigated by the fact that we do not look only at early hires, but also at employees joining the workplace in later stages of the firm lifecycle. Even so, we strongly encourage future research to investigate these questions in other settings, in order to corroborate and reinforce the external validity of our study.

Another question that directly arises from our study is whether the exposure to entrepreneurial role models inside organizations also relates to the future entrepreneurial performance of those engaging in entrepreneurship. Future research might also address the learning aspects of the entrepreneurial bossemployee interaction, namely identifyng factors, e.g., industry similarity, the performance of role models themselves, that improve the chances of learning from previous (same-gender) entrepreneurial bosses.

\section{ENDNOTES:}

\footnotetext{
${ }^{\text {i }}$ Goodall et al. (2011) find similar results in a professional basketball setting: a coach's acquired knowledge affects players' performance.

${ }^{\text {ii }}$ Recent studies on hybrid entrepreneurship (e.g., Folta et al., 2010) have shown that the processes of exiting paid employment and entering entrepreneurship are not necessarily sequential and can happen either simultaneously or in a reverse order. However, the timing of the events is not fundamental in our approach. We are mainly interested in studying the role played by bosses in employees' decisions to exit paid employment and to become entrepreneurs, and the influence of the boss in unlikely to be conditioned by the order of the events.

iii We made sure that the employer corresponds to the boss by checking more detailed classifications of occupations at the individual-level. These data confirm that those classified as bosses have often managerial roles in the firm.

iv Robustness checks based on the share of same-gender bosses in firms founded by teams of two or more entrepreneurs produced qualitatively similar results. In this case we studied how the share of same-gender bosses in the firm relates to employees' transitions into entrepreneurship. Since we cannot identify the relative importance of
} 
each entrepreneurial boss in these ventures, focusing on firms with a unique boss provides a clearer setting to study the mechanisms of interest.

${ }^{\mathrm{v}}$ In a comparison of the employees in our sample with a random sample of employees in established companies we observe that employees in new ventures are indeed different than those in established companies regarding some characteristics. However, the differences between female and male employees are not more or less pronounced in new vetures.

${ }^{\mathrm{vi}}$ Entrepreneurship experience by peers, spouses, or parents refers to any spell in self-employment or employer categories as a primary occupation, for at least one year. The estimations in column 4 (Table 4) are restricted to individuals whose parents are still alive, which reduces the number of observations. Alternative estimations considering the time spent in entrepreneurship or past entrepreneurship by the spouse or any of the parents do not produce significantly different results..

${ }^{\text {vii }}$ The non-significant influence of entrepreneurial mothers might also be explained by the fact that we study the likelihood of becoming an entrepreneur for employees who have already decided to join an entrepreneurial firm, whereas earlier studies analyzed this effect in a sample of individuals who had not all chosen for an entrepreneurial setting.

viii Similarity in age range is defined as an absolute age difference not higher than five years. Regarding education, we use detailed information on individual's highest education attained both in terms of the level of education (e.g., secondary, vocational, bachelor, etc.) and the broad educational field (e.g., industry specialization in the case of vocational education, or the academic field in the case of tertiary education). 


\section{REFERENCES}

Abowd, J. M., F. Kramarz, S. Woodcock. 2008. "Econometric analyses of linked employer-employee data.” In L. Mátyás, P. Sevestre (Eds.), The Econometrics of Panel Data, 22: 727-760. Berlin: Springer.

Artz, B. M., S. Taengnoi. 2016. "Do women prefer female bosses?”. Labour Economics, doi: 10.1016/j.labeco.2016.09.003

Artz, B.M., A. H. Goodall, A. J. Oswald. 2016. "Boss competence and worker well-being.” ILR Review, doi: 10.1177/0019793916650451.

Bagues, M. F., B. Esteve-Volart. 2010. "Can gender parity break the glass ceiling? Evidence from a repeated randomized experiment." Review of Economic Studies, 77(4): 1301-1328.

Barnir, A., W. E., Watson, H. M. Hutchins. 2011. "Mediation and moderated mediation in the relationship among role models, self-efficacy, entrepreneurial career intention, and gender." Journal of Applied Social Psychology, 41(2): 270-297.

Bednar, S., D. Gicheva, D. 2014. "Are female supervisors more female friendly?" American Economic Review, 104(5): 370-375.

Bhide, A. 1994. "How entrepreneurs craft strategies that work?" Harvard Business Review, 72(2): 150161.

Bosma, N., J. Hessels, V. Schutjens, M. van Praag, I. Verheul. 2012. "Entrepreneurship and role models." Journal of Economic Psychology, 33(2): 410-424.

Buttner, E. H., D. P. Moore. 1997. "Women's organizational exodus to entrepreneurship: self-reported motivations and correlates with success." Journal of Small Business Management, 35(1): 34-46.

Cardoso, A. R., R. Winter-Ebmer. 2010. "Female-led firms and gender wage policies." ILR Review, 64(1): 143-163.

Charness, G., U. Gneezy. 2012. "Strong evidence for gender differences in risk taking." Journal of Economic Behavior \& Organization, 83(1): 50-58.

Chlosta, S., H. Patzelt, S. B. Klein, C. Dormann. 2012. "Parental role models and the decision to become self-employed: The moderating effect of personality". Small Business Economics, 38(1): 121-138.

Cohen, L. E., J. P. Broschak. 2013. "Whose jobs are these? The impact of the proportion of female managers on the number of new management jobs filled by women versus men." Administrative Science Quarterly, 58(4): 509-541.

Cohen, P. N., M. L. Huffman. 2007. "Working for the women? Female managers and the gender wage gap.” American Sociological Review, 72(5): 681-704.

Cornelissen, T., C. Dustmann, U. Schönberg. 2016. "Peer effects in the workplace". American Economic Review (forthcoming).

Dahl, M. S., C. L., Dezsö, D. G. Ross. 2012. "Fatherhood and managerial style: How a male CEO's children affect the wages of his employees." Administrative Science Quarterly, 57(4): 669-693.

Dezsö, C. L., D. G. Ross. 2012. "Does female representation in top management improve firm performance? A panel data investigation.” Strategic Management Journal, 33(9): 1072-1089.

Dinlersoz, E. M., H. R. Hyatt, P. J. Hubert. 2016. "Who works for whom? Worker sorting in a model of entrepreneurship with heterogeneous labor markets". IZA Discussion Paper No. 9693.

Dobrev, S. D., W. P Barnett. 2005. "Organizational roles and transition to entrepreneurship." Academy of Management Journal, 48(3): 433-449. 
Elfenbein, D. W., B. H. Hamilton, T. R. Zenger. 2010. "The small firm effect and the entrepreneurial spawning of scientists and engineers.” Management Science, 56(4): 659-681.

Falck, O., S. Heblich, E. Luedemann. 2012. "Identity and entrepreneurship: do school peers shape entrepreneurial intentions?”. Small Business Economics, 39(1): 39-59.

Field, E., S. Jayachandran, R. Pande, N. Rigol. 2016. "Friendship at work: Can peer effects catalyze female entrepreneurship?” American Economic Journal: Economic Policy, 8(2): 125-153.

Folta, T., F. Delmar, K. Wennberg. 2010. "Hybrid entrepreneurship". Management Science, 56(2): 253269.

Forbes, D. P., P. S. Borchert, M. E. Zellmer-Bruhn, H. J. Sapienza. 2006 . "Entrepreneurial team formation: An exploration of new member addition". Entrepreneurship Theory \& Practice, 30(2), 225248.

Foss, N., J. Lyngsie. 2016. "The more, the merrier? Women in top management teams and entrepreneurship in established firms.” Strategic Management Journal, DOI: 10.1002/smj.2510.

Giannetti, M., A. Simonov. 2009."Social interactions and entrepreneurial activity." Journal of Economics \& Management Strategy, 18(3): 665-709.

Gibson, D. E. 2004. "Role models in career development: New directions for theory and research." Journal of Vocational Behaviour, 65(1): 134-156.

Giuliano, L., D. I. Levine, J. Leonard. 2011. "Racial bias in the manager-employee relationship. An analysis of quits, dismissals, and promotions at a large retail firm." The Journal of Human Resources, 46(1): 26-52.

Gneezy, U., A. Rustichini. 2004 . "Gender and competition at a young age.” American Economic Review, 94(2): 377-381.

Golub, B., M. O. Jackson. 2012. "How homophily affects the speed of learning and best-response dynamics." The Quarterly Journal of Economics, 127(3): 1287-1338.

Gompers, P., J. Lerner, J., D. Scharfstein. 2005. "Entrepreneurial spawning: Public corporations and the genesis of new ventures, 1986 to 1999." The Journal of Finance, 60(2): 577-614.

Goodall, A. H., L. M. Kahn, A. J. Oswald. 2011. "Why do leaders matter? A study of expert knowledge in a superstar setting." Journal of Economic Behavior \& Organization, 77(3): 265-284.

Greene, F. J., L. Han, L., S. Marlow. 2013. "Like mother, like daughter? Analyzing maternal influences upon women's entrepreneurial propensity." Entrepreneurship Theory \& Practice, 37(4): 687-711.

Greve, A., J. W. Salaff. 2003. "Social networks and entrepreneurship. Entrepreneurship Theory \& Practice, 28(1): 1-22.

Henrekson, M., T. Sanandaji. 2014. "Small business activity does not measure entrepreneurship." Proceedings of the National Academy of Sciences of the United States of America, 111(5): 1760-1765.

Hensvik, L. E. 2014. "Manager impartiality: Worker-firm matching and the gender wage gap." ILR Review, 67(2): 395-421.

Hoffmann, A., M. Junge, N. Malchow-Møller. 2015. "Running in the family: parental role models in entrepreneurship.” Small Business Economics, 44(1): 79-104.

Hughes, K. D. 2003. "Pushed or pulled? Women's entry into self-employment and small business ownership." Gender, Work, and Organization, 10(4): 432-454.

Jackson, C. K. 2013. "Match quality, worker productivity, and worker mobility: Direct evidence from teachers". The Review of Economics and Statistics, 95(4): 1096-1116. 
Kacperczyk, A. 2013. "Social influence and entrepreneurship: The effect of university peers on entrepreneurial entry." Organization Science, 24(3): 1-20.

Kane, A. A. 2010. "Unlocking knowledge transfer potential: Knowledge demonstrability and superordinate social identity”. Organization Science, 21(3): 643-660.

Kelley, D. J., A. Ali, C. Brush, A. C. Corbett, M. Majbouri, E. G. Rogoff. 2012. Global Entrepreneurship Monitor (GEM) 2012. United States Report, GEM Consortium.

Kleinbaum, A. M., T. E. Stuart, M. L. Tushman. 2011. "Discretion within constraint: homophily and structure in a formal organization”. Organization Science, 24(5): 1316-1336.

Kram, K. E., L. Isabella. 1985. "Mentoring alternatives: The role of peer relationships in career development." Academy of Management Journal, 28(1), 110-132.

Koellinger, P., M. Minniti, C. Schade. 2013. "Gender differences in entrepreneurial propensity." Oxford Bulletin of Economics and Statistics, 75(2): 214-234.

Kunze, A., A. R. Miller. 2014. "Women helping women? Evidence from private sector data on workplace hierarchies.” NBER Working Paper no. 20761.

Lazear, E. 2005. “Entrepreneurship.” Journal of Labor Economics, 23(4): 649-680.

Lazear, E. P., K. L. Shaw, C. T. Stanton. 2015. "The value of bosses.” Journal of Labor Economics, 33(4): 823-861.

Lerner, J., U. Malmendier. 2013. "With a little help from my (random) friends: Success and failure in post-business school entrepreneurship. The Review of Financial Studies, 26(10): 2411-2452.

Lindquist, M., J. Sol, M. van Praag. 2015. "Why do entrepreneurial parents have entrepreneurial children?" Journal of Labor Economics, 33(2): 269-296.

Lyness, K. S., M. E. Heilman. 2006. "When fit is fundamental: Performance evaluations and promotions of upper-level female and male managers." Journal of Applied Psychology, 91(4): 777-785.

Matsa, D. A., A. R. Miller. 2011. "Chipping away at the glass ceiling: Gender spillovers in corporate leadership.” American Economic Review, 101(3): 635-649.

Maume, D. J. 2011. "Meet the new boss... same as the old boss? Female supervisors and subordinate career prospects." Social Science Research, 40(2): 287-298.

McGinn, K. L., K. L. Milkman. 2013. "Looking up and looking out: Career mobility effects of demographic similarity among professionals." Organization Science, 24(4): 1041-1060.

McPherson, M., S. Lynn, J. M. Cook. 2001. "Birds of a Feather: Homophily in Social Networks.” Annual Review of Sociology, 27: 415-444.

Moroz, P. W., K. Hindle. 2012. "Entrepreneurship as a process: Toward harmonizing multiple perspectives". Entrepreneurship Theory \& Practice, 36(4): 781-818.

Nanda, R., J. B. Sørensen. 2010. "Workplace peers and entrepreneurship.” Management Science, 56(7): 1116-1126.

Obschonka, M., M. Goethner, R. K. Silbereisen, U. Cantner. 2012. "Social identity and the transition to entrepreneurship: The role of group identification with workplace peers." Journal of Vocational Behaviour, 80(1): 137-147.

OECD. 2014. Enhancing women's economic empowerment through entrepreneurship and business leadership in OECD countries. Final report, OECD Directorate for Employment, Labour and Social Affairs. 
Parker, S. C. 2009. "Why do small firms produce the entrepreneurs?" The Journal of Socio-Economics, 38(3): 484-494.

Phillips, D. J. 2005. "Organizational genealogies and the persistence of gender inequality: The case of Silicon Valley Law firms.” Administrative Science Quarterly, 50(3): 440-472.

Rabe-Hesketh, S., A. Skrondal. 2012. Multilevel and Longitudinal Modelling using Stata. Third Edition, Stata Press.

Reagans, R. 2005. "Preferences, identity, and competition: Predicting tie strength from demographic data". Management Science, 51(9): 1374-1383.

Reagans, R. 2011. "Close encounters: Analyzing how social similarity and propinquity contribute to strong network connections.” Organization Science, 22(4): 835-849.

Ruef, M., H. E. Aldrich, N. C. Carter. 2003. "The structure of founding teams: Homophily, strong ties, and isolation among US entrepreneurs.” American Sociological Review, 68(2): 195-222.

Sarasvathy, S. D. 2001. "Causation and effectuation: Toward a theoretical shift from economic inevitability to entrepreneurial contingency". The Academy of Management Review, 26(2): 243-263.

Shapiro, E., F. Haseltine, M. Rowe. 1978. "Moving up: Role models, mentors, and the 'patron system'." Sloan Management Review, 6(1): 19-47.

Smith, N., V. Smith, M. Verner. 2013. "Why are so few females promoted into CEO and Vice-President Positions? Danish empirical evidence 1997-2007.” ILR Review, 66(2): 380-408.

Sørensen, J. B. 2007. "Bureaucracy and entrepreneurship: Workplace effects on entrepreneurial entry." Administrative Science Quarterly, 52(3): 387-412.

Sørensen, J. B., M. A. Fassiotto. 2011. "Organizations as fonts of entrepreneurship.” Organization Science, 22(5): 1322-1331.

Sørensen, J. B., A. J. Sharkey. 2014. "Entrepreneurship as a mobility process.” American Sociological Review, 79(2): 328-249.

Srivastava, S. B., E. Sherman. 2015. "Agents of change or cogs in the machine? Reexamining the influence of female managers on the gender wage gap." American Journal of Sociology, 120(6): 17781808.

Stuart, T. E., W. W. Ding. 2006. "When do scientists become entrepreneurs? The social structural antecedents of commercial activity in the academic life sciences". American Journal of Sociology, 112(1): 97-114.

Thébaud, S. 2010. "Gender and entrepreneurship as a career choice: do self-assessments of ability matter?” Social Psychology Quarterly, 73(3): 288-304.

Thébaud, S. 2015. "Business as Plan B: Institutional foundations of gender inequality in entrepreneurship across 24 industrialized countries.” Administrative Science Quarterly, 60(4): 671-711.

Wilson, F., J. Kickul, D. Marlino. 2007. "Gender, entrepreneurial self-efficacy, and entrepreneurial career intentions: Implications for entrepreneurship education", Entrepreneurship: Theory and Practice, 31(3): 387-406.

Woodcock, S. D. 2015. "Match effects.” Research in Economics, 69(1): 100-121. 


\section{TABLES}

Table 1. Positioning the paper in existing research

Social interactions and individuals' decisions to become entrepreneurs

Organizational Boundaries

\begin{tabular}{|c|c|c|c|}
\hline \multirow{3}{*}{$\begin{array}{l}\text { Relative } \\
\text { hierarchical } \\
\text { position of } \\
\text { individuals } \\
\text { in the } \\
\text { network }\end{array}$} & & Outside Organizations & Inside Organizations \\
\hline & $\begin{array}{l}\text { Similar } \\
\text { (Peers) }\end{array}$ & $\begin{array}{l}\text { School peers (Falck et al., 2012) } \\
\text { University peers (Kacperzyk, 2013; Lerner \& } \\
\text { Malmendier, 2013) } \\
\text { Neighbors (Giannetti \& Simonov, 2009) } \\
\text { (Female) Friends (Field et al., 2016) }\end{array}$ & $\begin{array}{l}\text { Coworkers } \\
\text { (Stuart \& Ding, 2006; Nanda \& Sørensen, 2010) }\end{array}$ \\
\hline & $\begin{array}{l}\text { Superior } \\
\text { (Role } \\
\text { Models) }\end{array}$ & $\begin{array}{l}\text { Parents (often within same gender pairs) } \\
\text { (Chlosta et al., 2012; Greene et al., 2013; Hoffman et al., } \\
\text { 2015; Lindquist et al., 2015) Bosma e }\end{array}$ & $\begin{array}{l}\text { Employers/bosses } \\
\text { 1. (2012) }\end{array}$ \\
\hline
\end{tabular}

Table 2. Summary statistics at the worker-level, according to their decision to enter entrepreneurship a

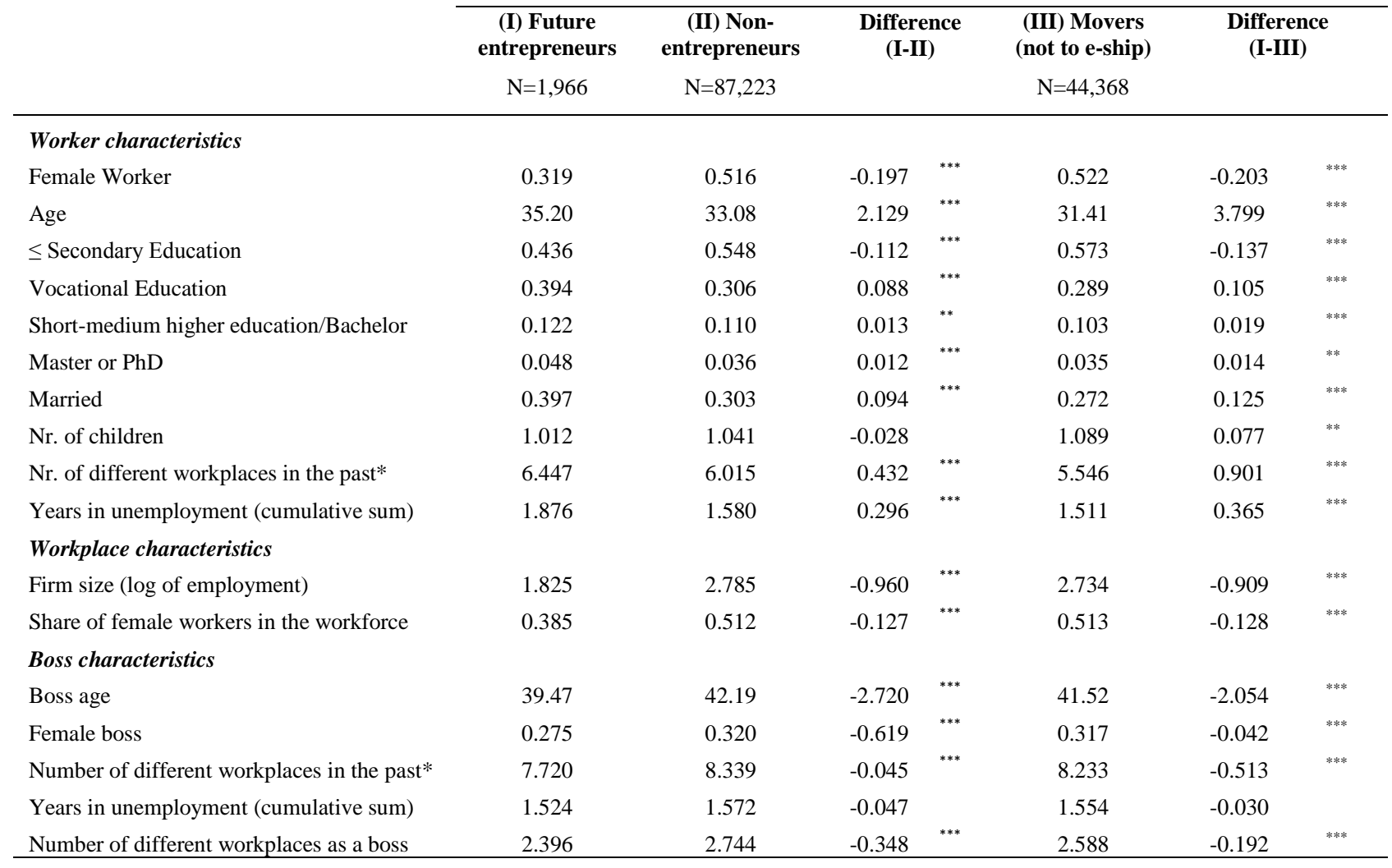

a Broader definition of entrepreneurship. The statistics refer to the year of an individual's entry in the firm, so "N" means "number of individuals".

${ }^{\mathrm{b}}$ It includes all workplaces, including those where the individual had short-term and part-time/secondary jobs. 
Table 3. The role of same gender bosses in employees' future transition into entrepreneurship

\begin{tabular}{|c|c|c|c|c|c|c|}
\hline & \multicolumn{3}{|c|}{ Broad e-ship definition } & \multicolumn{3}{|c|}{ Stricter e-ship definition } \\
\hline & Women & Men & All & Women & Men & All \\
\hline Same-gender Boss & $\begin{array}{l}0.5713^{\text {**** }} \\
(0.1324)\end{array}$ & $\begin{array}{l}0.1874 \\
(0.1282)\end{array}$ & $\begin{array}{l}0.0994 \\
(0.1234)\end{array}$ & $\begin{array}{l}1.0875^{* * * *} \\
(0.2489)\end{array}$ & $\begin{array}{l}0.4144^{*} \\
(0.2290)\end{array}$ & $\begin{array}{l}0.5003 \\
(0.2326)\end{array}$ \\
\hline Female Employee & & & $\begin{array}{l}-1.0958^{* * *} \\
(0.1514)\end{array}$ & & & $\begin{array}{l}-1.7603^{* * *} \\
(0.3888)\end{array}$ \\
\hline $\begin{array}{l}\text { Same-gender Boss*Female } \\
\text { Employee }\end{array}$ & & & $\begin{array}{l}0.3596^{* *} \\
(0.1815)\end{array}$ & & & $\begin{array}{l}0.7297^{*} \\
(0.4115)\end{array}$ \\
\hline $\begin{array}{l}\text { Year, worker tenure \& } \\
\text { industry dummies }\end{array}$ & Yes & Yes & Yes & Yes & Yes & Yes \\
\hline Nr. Observations & 75,189 & 63,083 & 138,272 & 72,147 & 61,323 & 133,470 \\
\hline Log Likelihood & $-2,806.1$ & $-5,069.6$ & $-7,922.0$ & -954.5 & $-1,881.4$ & $-2,866.5$ \\
\hline
\end{tabular}

Table 4. Comparing the same gender boss effect with peer effects, spouse and parental entrepreneurship effects (z-standardized coefficients)

4.1. Broader definition of entrepreneurship

\begin{tabular}{|c|c|c|c|c|c|c|c|c|}
\hline & \\
\hline & \multicolumn{4}{|c|}{ Women } & \multicolumn{4}{|c|}{ Men } \\
\hline & (1) & (2) & (3) & (4) & (1) & (2) & (3) & (4) \\
\hline \multirow[t]{2}{*}{ Same-gender Boss } & $0.2717^{* * * *}$ & $0.2699^{* * * *}$ & $0.2688^{* * * *}$ & $0.2926^{* * *}$ & 0.0885 & 0.0912 & 0.0915 & 0.0805 \\
\hline & $(0.0627)$ & $(0.0626)$ & $(0.0625)$ & $(0.0846)$ & $(0.0609)$ & $(0.0602)$ & $(0.0604)$ & $(0.0725)$ \\
\hline$\%$ Female coworkers with & & $0.0957^{* * * *}$ & $0.0957^{* * * *}$ & $0.1058^{* *}$ & & 0.0068 & 0.0067 & 0.0174 \\
\hline e-ship experience & & $(0.0371)$ & $(0.0370)$ & $(0.0515)$ & & $(0.0348)$ & $(0.0349)$ & $(0.0437)$ \\
\hline$\%$ Male coworkers with & & $0.0769^{*}$ & $0.0773^{*}$ & 0.0336 & & $0.0672^{* *}$ & $0.0672^{* * *}$ & 0.0610 \\
\hline e-ship experience & & $(0.0466)$ & $(0.0465)$ & $(0.0687)$ & & $(0.0313)$ & $(0.0314)$ & $(0.0389)$ \\
\hline \multirow[t]{2}{*}{ Spouse Entrepreneur } & & & 0.0464 & -0.0087 & & & -0.0238 & -0.1523 \\
\hline & & & $(0.0324)$ & $(0.0559)$ & & & $(0.0540)$ & $(0.1242)$ \\
\hline \multirow[t]{2}{*}{ Mother Entrepreneur } & & & & 0.0679 & & & & 0.0069 \\
\hline & & & & $(0.0516)$ & & & & $(0.0467)$ \\
\hline \multirow[t]{2}{*}{ Father Entrepreneur } & & & & $0.1347^{* *}$ & & & & $0.1241^{\text {**** }}$ \\
\hline & & & & $(0.0610)$ & & & & $(0.0345)$ \\
\hline Nr. Observations & 75,189 & 75,189 & 75,189 & 44,386 & 63,083 & 63,083 & 63,083 & 38,274 \\
\hline \multirow[t]{4}{*}{ Log Likelihood } & $-2,801.2$ & $-2,796.5$ & $-2,795.5$ & $-1,459.6$ & $-5,068.2$ & $-5,065.9$ & $-5,065.9$ & $-3,108.8$ \\
\hline & \multicolumn{8}{|c|}{ 4.2. Stricter definition of entrepreneurship } \\
\hline & \multicolumn{4}{|c|}{ Women } & \multicolumn{4}{|c|}{ Men } \\
\hline & $(1)$ & (2) & (3) & (4) & $(1)$ & $(2)$ & (3) & (4) \\
\hline Same-gender Boss & $\begin{array}{l}0.4943^{* * *} \\
(0.1135)\end{array}$ & $\begin{array}{l}0.5008^{* * * *} \\
(0.1117)\end{array}$ & $\begin{array}{l}0.5182^{* * * *} \\
(0.1175)\end{array}$ & $\begin{array}{l}0.5313^{* * * *} \\
(0.1331)\end{array}$ & $\begin{array}{l}0.1571^{*} \\
(0.0894)\end{array}$ & $\begin{array}{l}0.2044^{*} \\
(0.1084)\end{array}$ & $\begin{array}{l}0.2032^{*} \\
(0.1078)\end{array}$ & $\begin{array}{l}0.1548 \\
(0.1264)\end{array}$ \\
\hline $\begin{array}{l}\% \text { Female coworkers with } \\
\text { e-ship experience }\end{array}$ & & $\begin{array}{l}0.0877 \\
(0.0668)\end{array}$ & $\begin{array}{l}0.0907 \\
(0.0709)\end{array}$ & $\begin{array}{l}0.1637^{* *} \\
(0.0646)\end{array}$ & & $\begin{array}{l}0.0141 \\
(0.0609)\end{array}$ & $\begin{array}{l}0.0142 \\
(0.0606)\end{array}$ & $\begin{array}{l}-0.0036 \\
(0.0798)\end{array}$ \\
\hline $\begin{array}{l}\% \text { Male coworkers with } \\
\text { e-ship experience }\end{array}$ & & $\begin{array}{l}0.0204 \\
(0.0921)\end{array}$ & $\begin{array}{l}0.0230 \\
(0.0965)\end{array}$ & $\begin{array}{l}-0.0583 \\
(0.1105)\end{array}$ & & $\begin{array}{l}0.1043^{*} \\
(0.0554)\end{array}$ & $\begin{array}{l}0.1039^{*} \\
(0.0551)\end{array}$ & $\begin{array}{l}0.1060 \\
(0.0653)\end{array}$ \\
\hline Spouse Entrepreneur & & & $\begin{array}{l}0.1047^{*} \\
(0.0586)\end{array}$ & $\begin{array}{l}-0.0152 \\
(0.0873)\end{array}$ & & & $\begin{array}{l}0.0918 \\
(0.0742)\end{array}$ & $\begin{array}{l}-0.0237 \\
(0.1371)\end{array}$ \\
\hline Mother Entrepreneur & & & & 0.0947 & & & & -0.1821 \\
\hline Father Entrepreneur & & & & $\begin{array}{l}0.1413^{*} \\
(0.0855)\end{array}$ & & & & $\begin{array}{l}0.1814^{* * * *} \\
(0.0554)\end{array}$ \\
\hline Nr. Observations & 72,147 & 72,147 & 72,147 & 42,472 & 61,323 & 61,323 & 61,323 & 37,323 \\
\hline Log Likelihood & -955.9 & -954.5 & -952.6 & -543.7 & $-1,882.9$ & $-1,881.6$ & $-1,880.9$ & $-1,244.4$ \\
\hline
\end{tabular}


Table 5. Boss gender, employees' exit, and current wages

\begin{tabular}{llll}
\hline & $\begin{array}{l}\text { Probability of moving } \\
\text { to another job }\end{array}$ & $\begin{array}{l}\text { Probability of moving } \\
\text { to unemployment }\end{array}$ & $\begin{array}{l}\text { Hourly wages } \\
(\log )\end{array}$ \\
\hline Female Employee & $0.0673^{* * *}$ & 0.0535 & $-0.1028^{* * * *}$ \\
& $(0.0189)$ & $(0.0778)$ & $(0.0056)$ \\
Female Boss & $0.1049^{* * *}$ & $0.2501^{* * *}$ & $-0.0313^{* * *}$ \\
& $(0.0235)$ & $(0.0892)$ & $(0.0112)$ \\
Female Employee*Female Boss & $-0.1059^{* * *}$ & $-0.2841^{* * *}$ & $0.0305^{* * *}$ \\
& $(0.0279)$ & $(0.1090)$ & $(0.0094)$ \\
\hline Number of Observations & 141,776 & 141,776 & 106,104 \\
Log Likelihood & $-69,788.1$ & $-12,378.4$ & $-63,929.1$ \\
\hline
\end{tabular}

Three-level mixed models (complementary log-logistic model in the first two columns and linear model for $\log$ (wages); individuals reporting zero wages were excluded from the estimation.). *, **, and *** mean significant at $10 \%, 5 \%$, and $1 \%$ levels, respectively. Values in parenthesis are standard errors. All the specifications include the same control variables specified in Table 3.

Table 6. The female boss effect on female employees' entrepreneurship choices: moderator effects of workplace size, share of female coworkers, male- and female-dominated industries

\begin{tabular}{|c|c|c|c|c|}
\hline & (1) & (2) & (3) & (4) \\
\hline Female Boss & $\begin{array}{l}0.8899^{* * *} \\
(0.2033)\end{array}$ & $\begin{array}{l}1.1587^{* * *} \\
(0.3736)\end{array}$ & $\begin{array}{l}0.4110^{* * *} \\
(0.1294)\end{array}$ & $\begin{array}{l}0.4343^{* * *} \\
(0.1406)\end{array}$ \\
\hline Workplace size & $\begin{array}{l}-0.4243^{* * *} \\
(0.0679)\end{array}$ & & & \\
\hline Female Boss*Workplace size & $\begin{array}{l}-0.1572^{* *} \\
(0.0716)\end{array}$ & & & \\
\hline$\%$ Female workers in the workforce & & $\begin{array}{l}-0.5605^{*} \\
(0.3237)\end{array}$ & & \\
\hline$\%$ Female workers in the workforce*Female Boss & & $\begin{array}{l}-0.7562^{*} \\
(0.4487)\end{array}$ & & \\
\hline Male-dominated sector & & & $\begin{array}{l}-0.7590 \\
(0.5268)\end{array}$ & \\
\hline Female Boss* Male-dominated sector & & & $\begin{array}{l}1.2554^{* *} \\
(0.6297)\end{array}$ & \\
\hline Female-dominated sector & & & & $\begin{array}{l}-0.5610 \\
(0.3508)\end{array}$ \\
\hline Female Boss* Female-dominated sector & & & & $\begin{array}{l}0.2604 \\
(0.3237)\end{array}$ \\
\hline Nr. Observations & 75,189 & 75,189 & 75,189 & 75,189 \\
\hline Log Likelihood & $-2,789.8$ & $-2,799.7$ & $-2,805.9$ & $-2,806.8$ \\
\hline
\end{tabular}

Three-level mixed complementary log-logistic models. *,**, and *** mean significant at $10 \%, 5 \%$, and $1 \%$ levels, respectively. Values in parenthesis are standard errors. Estimations restricted to female employees. All the specifications include the same control variables specified in Table 3 and refer to the broader definition of entrepreneurship. The results obtained using the stricter definition of entrepreneurship are qualitatively similar and are available upon request. 
Table 7. The female boss effect on female employees' entrepreneurship choices: low versus high performance firms

\begin{tabular}{lllll} 
& \multicolumn{2}{c}{ Firm sales } & \multicolumn{2}{c}{ Labor productivity } \\
\cline { 2 - 5 } & Below median & Above median & Below median & Above median \\
\hline Female Boss & 0.2021 & $0.7319 * * *$ & 0.1959 & $0.7073 * * *$ \\
& $(0.1626)$ & $(0.2168)$ & $(0.1569)$ & $(0.1830)$ \\
\hline Nr. Observations & 23,284 & 21,210 & 29,792 & 14,262 \\
Log Likelihood & $-1,262.4$ & -800.5 & $-1,266.7$ & -806.3 \\
\hline
\end{tabular}

Three-level mixed complementary log-logistic models. *** means significant at $1 \%$ level. Values in parenthesis are standard errors. Estimations restricted to female employees. All the specifications include the same control variables specified in Table 3 and refer to the broader definition of entrepreneurship. The results obtained using the stricter definition of entrepreneurship are qualitatively similar and are available upon request.

Table 8. The female boss effect on female employees' entrepreneurship choices: moderator effects of employee-boss homophily on other individual attributes

\begin{tabular}{|c|c|c|c|c|}
\hline & & & & \\
\hline & (1) & $(2)$ & (3) & (4) \\
\hline \multirow[t]{2}{*}{ Female Boss } & $0.4096^{* * * *}$ & $0.3608^{* *}$ & $0.2367^{*}$ & $0.2740^{*}$ \\
\hline & $(0.1559)$ & $(0.1517)$ & $(0.1408)$ & $(0.1505)$ \\
\hline \multirow[t]{2}{*}{ Worker-Boss similar age } & 0.0385 & & & \\
\hline & $(0.1915)$ & & & \\
\hline \multirow[t]{2}{*}{ Female Boss*Worker-Boss similar age } & $0.5029^{* *}$ & & & \\
\hline & $(0.2430)$ & & & \\
\hline \multirow[t]{2}{*}{ Worker-Boss similar education background } & & 0.1738 & & \\
\hline & & $(0.2296)$ & & \\
\hline \multirow{2}{*}{$\begin{array}{l}\text { Female Boss*Worker-Boss similar education } \\
\text { background }\end{array}$} & & $0.7845^{* * *}$ & & \\
\hline & & $(0.2764)$ & & \\
\hline \multirow[t]{2}{*}{ Worker-Boss similar birth place } & & & 0.0557 & \\
\hline & & & $(0.2131)$ & \\
\hline \multirow[t]{2}{*}{ Female Boss*Worker-Boss similar birth place } & & & $0.7604^{* * * *}$ & \\
\hline & & & $(0.2656)$ & \\
\hline \multirow[t]{2}{*}{ Both worker and boss have children } & & & & -0.2335 \\
\hline & & & & $(0.2045)$ \\
\hline \multirow[t]{2}{*}{ Female Boss*Both worker and boss have children } & & & & $0.5419^{* *}$ \\
\hline & & & & $(0.2412)$ \\
\hline Nr. Observations & 75,189 & 71,166 & 74,741 & 75,070 \\
\hline Log Likelihood & $-2,800.6$ & $-2,645.8$ & $-2,785.2$ & $-2,798.6$ \\
\hline
\end{tabular}

Three-level mixed complementary log-logistic models. *,**, and *** mean significant at $10 \%, 5 \%$, and $1 \%$ levels, respectively. Values in parenthesis are standard errors. Estimations restricted to female employees. All the specifications include the same control variables specified in Table 3 and refer to the broader definition of entrepreneurship. The results obtained using the stricter definition of entrepreneurship are qualitatively similar and are available upon request. 


\section{Appendix}

Table A.I. Summary statistics at the worker-level, according to their gender and decision to enter entrepreneurship ${ }^{\mathrm{a}}$

\begin{tabular}{|c|c|c|c|c|c|c|c|c|}
\hline & \multirow{2}{*}{\multicolumn{4}{|c|}{ Men }} & \multirow{2}{*}{\multicolumn{4}{|c|}{ Women }} \\
\hline & & & & & & & & \\
\hline & \multirow{2}{*}{$\begin{array}{c}\text { Future } \\
\text { entrepreneurs } \\
\mathrm{N}=1,349 \\
\end{array}$} & \multirow{2}{*}{$\begin{array}{c}\text { Non- } \\
\text {-entrepreneurs } \\
\mathrm{N}=42,217 \\
\end{array}$} & \multicolumn{2}{|c|}{ Difference } & \multirow{2}{*}{$\begin{array}{c}\text { Future } \\
\text { entrepreneurs } \\
\mathrm{N}=617 \\
\end{array}$} & \multirow{2}{*}{$\begin{array}{c}\text { Non- } \\
\text {-entrepreneurs } \\
\mathrm{N}=45,006\end{array}$} & \multicolumn{2}{|c|}{ Difference } \\
\hline & & & & & & & & \\
\hline \multicolumn{9}{|l|}{ Worker characteristics } \\
\hline Age & 34.56 & 33.31 & 1.253 & ${ }^{* * *}$ & 36.58 & 32.86 & 3.724 & ${ }^{* * *}$ \\
\hline$\leq$ Secondary Education & 0.478 & 0.551 & -0.073 & ${ }^{* * *}$ & 0.355 & 0.545 & -0.190 & ${ }^{* * *}$ \\
\hline Vocational Education & 0.397 & 0.323 & 0.074 & $* * *$ & 0.388 & 0.291 & 0.096 & ${ }^{* * *}$ \\
\hline Short-medium higher education/Bachelor & 0.085 & 0.086 & 0.001 & & 0.193 & 0.130 & 0.062 & ${ }^{* * *}$ \\
\hline Master or $\mathrm{PhD}$ & 0.039 & 0.040 & -0.001 & & 0.066 & 0.033 & 0.032 & ${ }^{* * *}$ \\
\hline Married & 0.378 & 0.285 & 0.093 & *** & 0.438 & 0.319 & 0.119 & *** \\
\hline Number of children & 0.979 & 0.945 & 0.034 & & 1.083 & 1.129 & -0.046 & \\
\hline Nr. of different workplaces in the past ${ }^{b}$ & 6.388 & 6.282 & 0.105 & & 6.573 & 5.764 & 0.809 & *** \\
\hline Years in unemployment (cumulative sum) & 1.754 & 1.544 & 0.210 & ${ }^{* * *}$ & 2.136 & 1.613 & 0.523 & ${ }^{* * *}$ \\
\hline \multicolumn{9}{|l|}{ Workplace characteristics } \\
\hline Firm size (log of employment) & 1.746 & 2.605 & -0.858 & ${ }^{* * *}$ & 1.992 & 2.954 & -0.962 & ${ }^{* * *}$ \\
\hline Share of female workers in the workforce & 0.182 & 0.248 & -0.066 & $* * *$ & 0.818 & 0.760 & 0.058 & *** \\
\hline \multicolumn{9}{|l|}{ Boss characteristics } \\
\hline Boss age & 38.65 & 41.33 & -2.681 & $* * *$ & 41.21 & 42.99 & -1.780 & *** \\
\hline Female boss & 0.152 & 0.172 & -0.019 & $* *$ & 0.537 & 0.459 & 0.078 & ${ }^{* * *}$ \\
\hline Nr. of different workplaces in the past ${ }^{b}$ & 7.493 & 8.401 & -0.908 & $* * *$ & 8.204 & 8.282 & -0.077 & \\
\hline Years in unemployment (cumulative sum) & 1.508 & 1.515 & -0.007 & & 1.559 & 1.625 & -0.066 & \\
\hline Number of different workplaces as a boss & 2.324 & 2.695 & -0.371 & $* * *$ & 2.551 & 2.790 & -0.240 & $* * *$ \\
\hline
\end{tabular}

${ }^{\mathrm{b}}$ It includes all workplaces, including those where the individual had short-term and part-time/secondary jobs. 
Table A.II. Industry-distribution of workplaces founded by men and women

Female bosses

Wholesale and retail trade

$25,7 \%$

Accommodation and food service activities

$21,2 \%$

Other technical business services

$13,0 \%$

Educational support activities and health care services

$10,0 \%$

Sports, amusement and recreation activities

$6,3 \%$

Primary sector (total)

$4,4 \%$

Construction

$4,3 \%$

Manufacturing industries (total)

$2,4 \%$

Repair of personal goods

$2,4 \%$

Business consultancy activities

$2,0 \%$

Other services*

$8,1 \%$

Total (4,036 newly founded workplaces)

$100 \%$

* Services where the share of female-owned workplaces is smaller than $2 \%$

\section{Male bosses}

Wholesale and retail trade

$14,9 \%$

Construction

$14,7 \%$

Accommodation and food service activities

$14,1 \%$

Agriculture and horticulture

$13,2 \%$

Other technical business services

$10,8 \%$

Transport and storage services

$7,5 \%$

Manufacturing industries

$5,1 \%$

Educational support activities and health care services

$4,5 \%$

Business consultancy activities

$3,3 \%$

Other primary sector activities

$1,4 \%$

Other services*

$10,6 \%$

Total (9,895 newly founded workplaces)

$100 \%$

* Services where the share of male-owned workplaces is smaller than $2 \%$ 
Table A.III. The role of same gender bosses in employees' future transitions into entrepreneurship

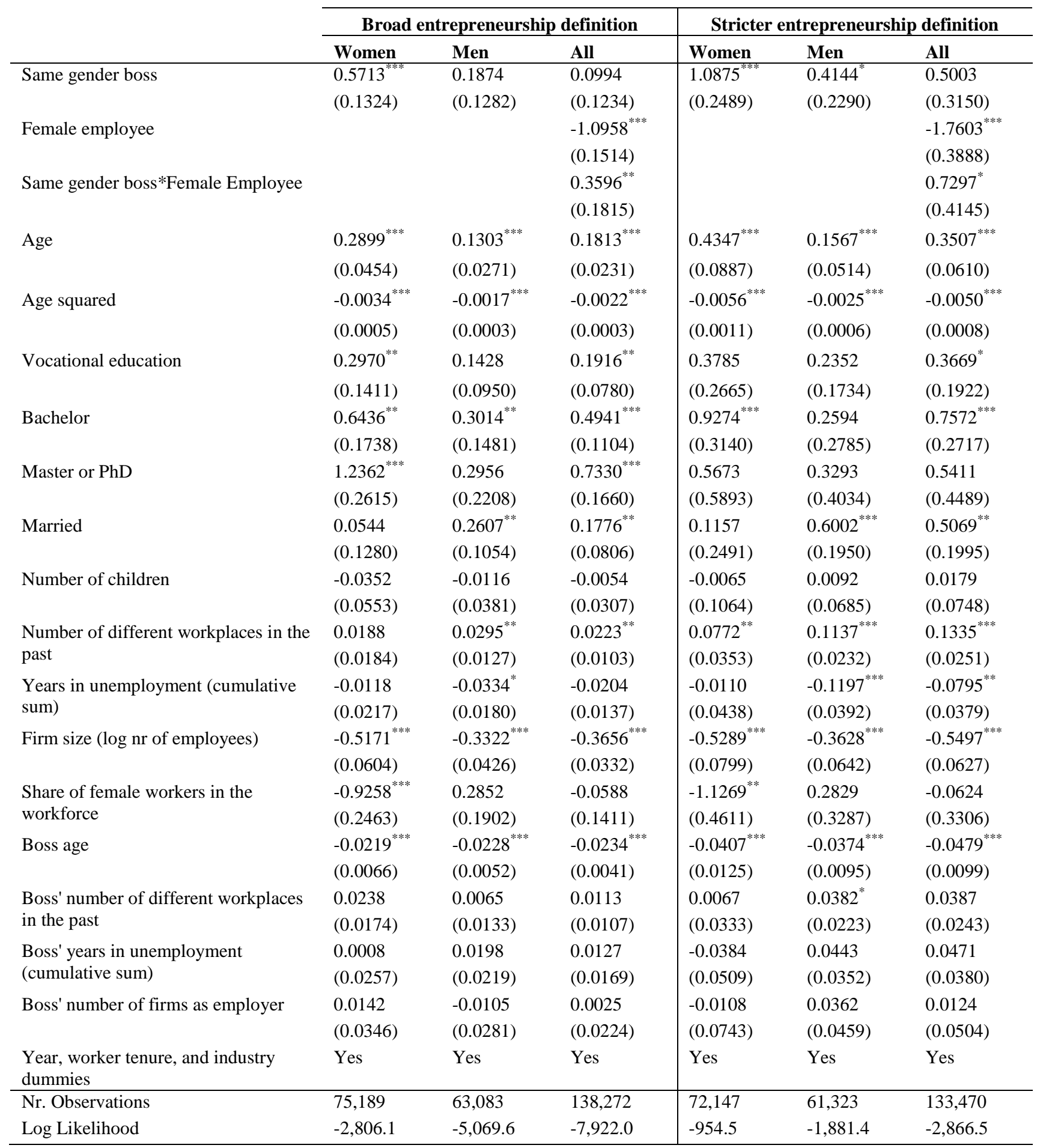

Three-level mixed complementary log-logistic model. *,**, and *** mean significant at $1 \%, 5 \%$, and $10 \%$ levels, respectively.

Values in parenthesis are standard errors. These correspond to the global specifications summarized in Table 3 of the paper. 